\title{
DOWNY MILDEW (Plasmopara halstedii) INFECTION IN HIGH OLEIC SUNFLOWER HYBRIDS IN NORTHERN ITALY
}

\author{
Baldini, M. ${ }^{{ }^{*}}$, Danuso, F. ${ }^{1}$, Turi, M. $^{2}$, Sandra, M. ${ }^{1}$, Raranciuc, S. ${ }^{3}$ \\ ${ }^{1}$ Dipartimento di Scienze Agrarie ed Ambientali, Università di Udine, \\ via delle Scienze, 208, 33100 Udine \\ ${ }^{2}$ Azienda Sperimentale "E. Servadei", Università di Udine, \\ via Pozzuolo, 324, 33100 Udine \\ ${ }^{3}$ Pathologist of Agricultural Research and Development Institute. \\ N. Titulescu, 2, 915200 Fundulea, Calarasi, Romania
}

Received: October 15, 2006

Accepted: December 05, 2006

\section{SUMMARY}

This study was conducted to evaluate the behavior of some high oleic sunflower hybrids towards the race of Plasmopara halstedii present in the environment and to analyze the main climatic factors affecting development and spread of the disease in order to draw up the basis for a prediction model of disease incidence. The race was determined by means of artificial infection of differential inbred lines in a growth chamber experiment and a field trial was also done to study the effects of the factors genotype, sowing time and seed dressing on the infection percentage of $P$. halstedii during different sunflower growing stages. The $P l$ genes responsible for resistance to race 700 , detected in the trial area and named according to the international code, were absent in all the high oleic hybrids studied, which, however, manifested a partial resistance to downy mildew, probably due to the partial polygenic, non-qualitative and non-specific resistance to the race detected. Seed treatment with metalaxyl helped to limit the severity of $P$. halstedii attack to $5 \%$ of plants infected, but with a maximum of $19.6 \%$ in the susceptible check. Concerning the environmental conditions, water availability did not result as being limiting for the infection, whereas the most favorable mean air temperatures during the 5 days following sowing ranged from 10 to $15^{\circ} \mathrm{C}$.

Key words: high oleic sunflower, downy mildew, Plasmopara halstedii, infection prediction model, partial genetic resistance

* Corresponding author: Phone: +390432558663; Fax: +390432558603; e-mail: baldini@uniud.it 


\section{INTRODUCTION}

Downy mildew in sunflower caused by Plasmopara halstedii (Farlow) Berl and De Tony is a common disease in large farming areas with a cool and rainy spring, which is ideal for this oil crop. The primary infection is initiated by oospores germination and zoospores production, which systemically infect young seedlings causing either death or stunting the plant. The spread of infection in a crop depends on different factors such as the initial inoculum level in the soil and climatic conditions. Soil and air moisture and temperature are particularly important during the germination and early growth stage of sunflower (Delanoe and Hamant, 1972; Zimmer and Hoes, 1978; Kolte, 1985; Sackston, 1981). Despite this disease being widespread, the economic risk of sunflower crop has been reduced by the genetic resistance of cultivated varieties (Vear and Leclercq, 1971; Zimmer and Kinmann, 1972) and the effective fungicides used for seed treatment (metalaxyl) (Iliescu, 1979).

After identification in the 1970s of the first physiological race of downy mildew in several countries, the pathogen further evolved with the appearance of new virulent races. Consequently, the complete and dominant genetic resistance, which had been obtained by the introduction of $P l$ race-specific resistance genes (Gossen and Sackston, 1968; Vranceanu et al., 1981; Vear et al., 2000), has become more and more complicated to introduce and less durable, so making the work of breeders harder. Moreover, in some important sunflower growing areas in countries such as France (Albourie et al., 1998), USA (Gulya, 2000) and Spain (Molinero-Ruiz et al., 2000), there are reports on new fungus races with decreased sensitivity to metalaxyl. The current concern of the international scientific community over this problem is thus understandable, especially now, when sunflower has new expansion prospects as an "energy crop".

This study was conducted with the following objectives: 1 ) to identify the $P$. halstedii race present in our environment; 2) to evaluate the resistance to the race present in some high oleic sunflower hybrids currently being investigated for either food or energy purposes; 3 ) to analyze the main climate factors that affect the development and spread of the disease in order to draw up the basis for a prediction model of disease incidence.

\section{MATERIAL AND METHODS}

\section{Field trials}

Experiments were conducted at "E. Servadei" experimental farm of the University of Udine, Udine, north-eastern Italy (92 $\mathrm{m}$ a.s.1., $45^{\circ} 02^{\prime} \mathrm{N}$ and $13^{\circ} 13^{\prime} \mathrm{E}$ ) in 2004 and 2005, on a shallow sandy-loam soil (about $50 \mathrm{~cm}$ ), lying on a gravel substrate.

The availability of inoculum in the environment was assured by the previous 4 years of sunflower monoculture, with frequent systemic downy mildew symptoms on plants. Daily weather data (air temperature and rainfall) were recorded during 
the sunflower growing season (Figure 1). The experimental factors were year, genotype, sowing time and seed treatment.
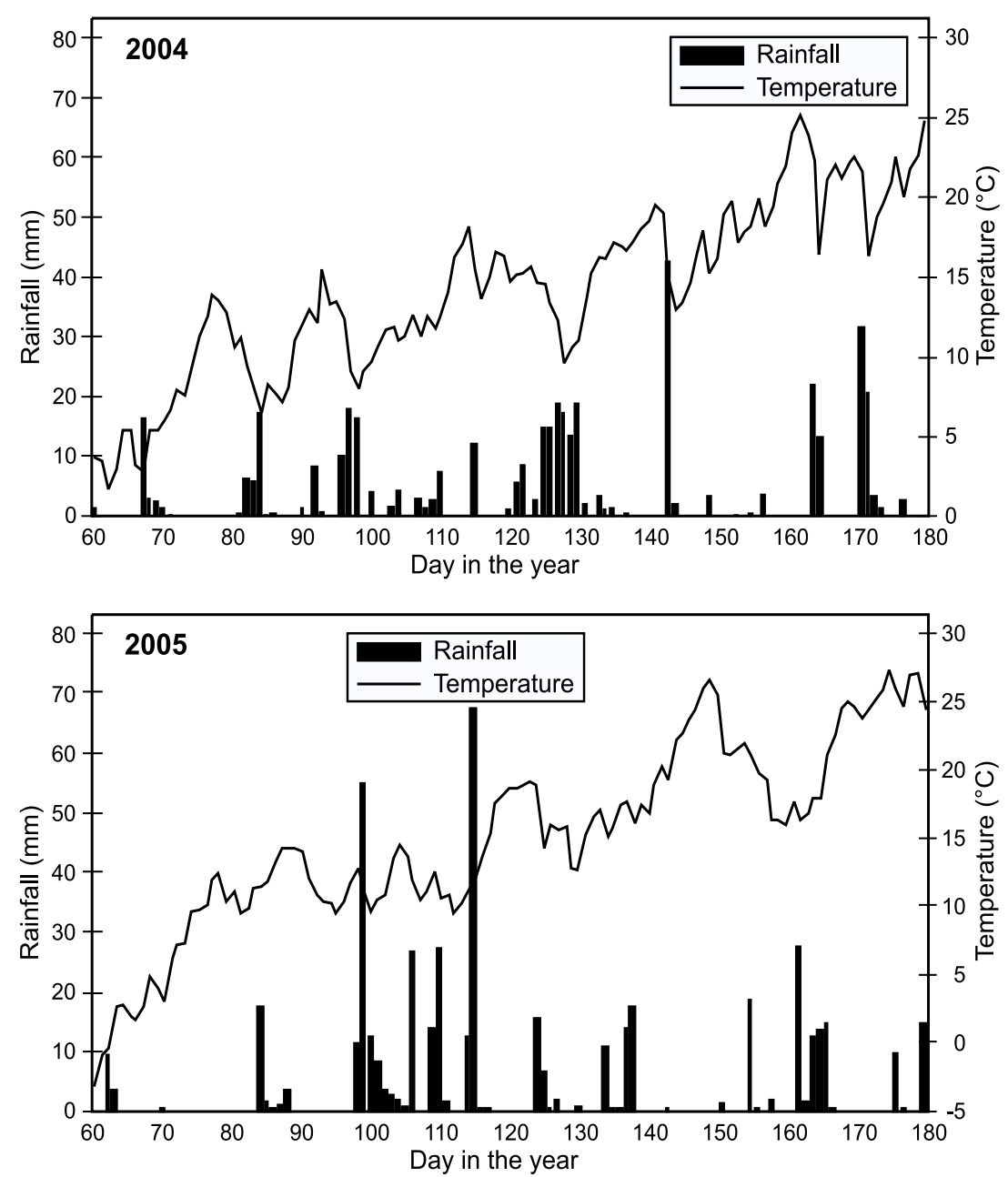

Figure 1: Rainfall and mean daily air temperature for the period March-June, 2004 and 2005

Seven high-oleic sunflower hybrids of various origins and unknown response to $P$. halstedii were evaluated. Two checks were also included as differential lines: HA 304 and HA 355, universally susceptible and resistant to all known downy mildew races, respectively (Table 1 ).

The experimental plots were sown manually on five different dates: April 5, 15, 23 and May 3, 11 in 2004, and April 6, 15, 27 and May 9, 17 in 2005, so as to obtain a wide range of weather conditions in order to estimate their effect on disease development. 
Table 1: High oleic hybrids and check lines used in experimental field

\begin{tabular}{cc}
\hline Cultivar & Supplier \\
\hline HA 335 (check) & Public \\
HA 304 (check) & Public \\
Latino & Advanta \\
Gamasol & Dekalb \\
Majus & KWS \\
Marko & Syngenta \\
Proleic & SIS \\
Olsavil & Pionieer \\
Goleador & ISEA \\
\hline
\end{tabular}

Other experimental factors were the presence or absence of seed dressing treatment. In the commercial hybrids the "no seed dressing" treatment was obtained by careful seed hull removal before sowing, while in the two differential lines the "seed dressing" treatment was done by mixing metalaxyl (Apron 20\% LS) with the seeds at a concentration of $2 \mathrm{mg}$ of a.i. per $\mathrm{kg}$ of seed (Molinero Ruiz et al., 2000).

Statistical analysis was done by means of ANOVA, keeping the years separate. The experimental design was a strip-split plot with two replications, in which sowing date was the main treatment in the strip-plot, genotype in the main-plot and seed treatment in the sub-plot.

The experimental unit was a two-row plot, $5 \mathrm{~m}$ long with $50 \mathrm{~cm}$ row spacing and a density of 10 seeds $\mathrm{m}^{2}$ for a total of 50 seeds per unit.

The correlation was calculated between the percentage of infection (average of the years of the "no dressing" susceptible genotype, HA 304) and two weather factors: rainfall and air temperature. More specifically, accumulated rainfall and the average temperatures were calculated for different periods $(5,10,20$ and 30 days before and after each sowing date).

Table 2: Reaction of sunflower differential lines to 11 downy mildew races and the triplet codes correspondent of international race name ( $\mathrm{R}=$ resistant; $\mathrm{S}=$ susceptible).

\begin{tabular}{|c|c|c|c|c|c|c|c|c|c|c|c|}
\hline \multirow{2}{*}{ Differential lines } & \multicolumn{11}{|c|}{ Races of $P$. halstedii } \\
\hline & 1 & 2 & 3 & 4 & 5 & 6 & 7 & 8 & 9 & 10 & 11 \\
\hline \multicolumn{12}{|c|}{ Set 1} \\
\hline D-1 (HA-304) & S & S & S & $S$ & $S$ & S & S & S & $S$ & S & $S$ \\
\hline D-2 (RHA-265) & $\mathrm{R}$ & S & S & S & S & S & $S$ & S & $S$ & S & $S$ \\
\hline D-3 (RHA-274) & $\mathrm{R}$ & $\mathrm{R}$ & S & S & $S$ & $\mathrm{R}$ & $\mathrm{R}$ & $S$ & $\mathrm{R}$ & S & $S$ \\
\hline \multicolumn{12}{|c|}{ Set 2} \\
\hline D-5 (PM17) & $\mathrm{R}$ & $\mathrm{R}$ & $\mathrm{R}$ & $S$ & $S$ & $\mathrm{R}$ & S & $\mathrm{R}$ & S & $\mathrm{R}$ & $\mathrm{R}$ \\
\hline D-6 (803-1) & $\mathrm{R}$ & $R$ & $R$ & $\mathrm{R}$ & $\mathrm{S}$ & $\mathrm{R}$ & $R$ & $\mathrm{R}$ & $\mathrm{R}$ & $\mathrm{R}$ & $\mathrm{R}$ \\
\hline \multicolumn{12}{|c|}{ Set 3} \\
\hline D-7 (HA-R4) & $\mathrm{R}$ & $\mathrm{R}$ & $\mathrm{R}$ & $\mathrm{R}$ & $\mathrm{R}$ & R & $\mathrm{R}$ & $R$ & $\mathrm{R}$ & S & $S$ \\
\hline D-8 (QHP1) & $\mathrm{R}$ & $\mathrm{R}$ & $R$ & $\mathrm{R}$ & $\mathrm{R}$ & $R$ & $\mathrm{R}$ & $R$ & $\mathrm{R}$ & S & $\mathrm{R}$ \\
\hline D-9 (HA-355) & $\mathrm{R}$ & $\mathrm{R}$ & $\mathrm{R}$ & $\mathrm{R}$ & $\mathrm{R}$ & $R$ & $\mathrm{R}$ & $\mathrm{R}$ & $\mathrm{R}$ & $\mathrm{R}$ & $\mathrm{R}$ \\
\hline Triplet coding system & 100 & 300 & 700 & 730 & 770 & 310 & 330 & 710 & 330 & 703 & 711 \\
\hline
\end{tabular}


In each experimental unit, plants that showed the typical symptoms of natural $P$. halstedii infection (sporulation on leaves, leaf yellowing and stunting) were recorded, and the percentage of infected plants was subsequently calculated in each experimental unit. The observations were made in correspondence with five phenological plant stages: cotyledon extension, 2-4, 6-8, 10-12 and more than 12 true leaves.

With a view to characterizing the race of sunflower downy mildew present in the trial environment, the public differential lines defined from Tourvieille de Labrouhe et al. (2000) were used (Table 2). The method suggested by Molinero-Ruiz et al. (2002) was followed for inoculum preparation and race identification.

\section{RESULTS AND DISCUSSION}

\section{Race identification}

The results of the infection test on the differential lines showed an average of $60-70 \%$ of infected plants, with marked sporulation on the leaves only in the three differential lines belonging to the first set (Table 2). This result, according to the international code (Tourvieille de Labrouhe et al., 2000), indicates the presence of race 700 .

\section{Genotype}

In the field, the percentage of downy mildew infected plants was influenced by the interaction genotype $\mathrm{x}$ dressing treatment.

With a few exceptions, the seed dressing treatment effect was revealed by a significant decrease in the level of infection, in all genotypes and both years, compared to no seed dressing (Figure 2). The genotypes with an increased percentage of infected plants confirmed this tendency independently of the presence or absence of dressing treatment, especially in 2004, underlining that the fungicide treatment is less effective on the genotypes with genetic susceptibility.

Table 3: Mean, minimum and maximum values of plants infected (\%) by Plasmopara halstedii, recorded in resistant (HA 335), susceptible (HA 304) differential lines and on high oleic hybrids in 2004-2005. Data are referred to no seed dressing and first sowing times

\begin{tabular}{lcccc}
\hline Year & High oleic hybrid & $\begin{array}{c}\text { HA 335 } \\
(\%)\end{array}$ & $\begin{array}{c}\text { HA 304 } \\
\text { (resistant check) (\%) }\end{array}$ & (susceptible check) (\%) \\
\hline 2004 & Mean & 7.8 & 0 & 34.2 \\
& Min & 1.7 & 0 & 24.7 \\
& Max & 22.3 & 0 & 43.8 \\
\hline 2005 & Mean & 20.4 & 0 & 68.9 \\
& Min & 7.7 & 0 & 68.7 \\
& Max & 33.6 & 0 & 69.1 \\
\hline
\end{tabular}

Considering the genotypes, the differential line HA 335, carrying $P l$ resistance genes to all the known races, never showed any symptom, while the highest level of attack was in the untreated susceptible differential line (HA 304), with 43.8 and 
$69.1 \%$ of infection in the first sowing date. These values confirm a relevant presence of inoculum in the soil of the field trial (Figure 2).
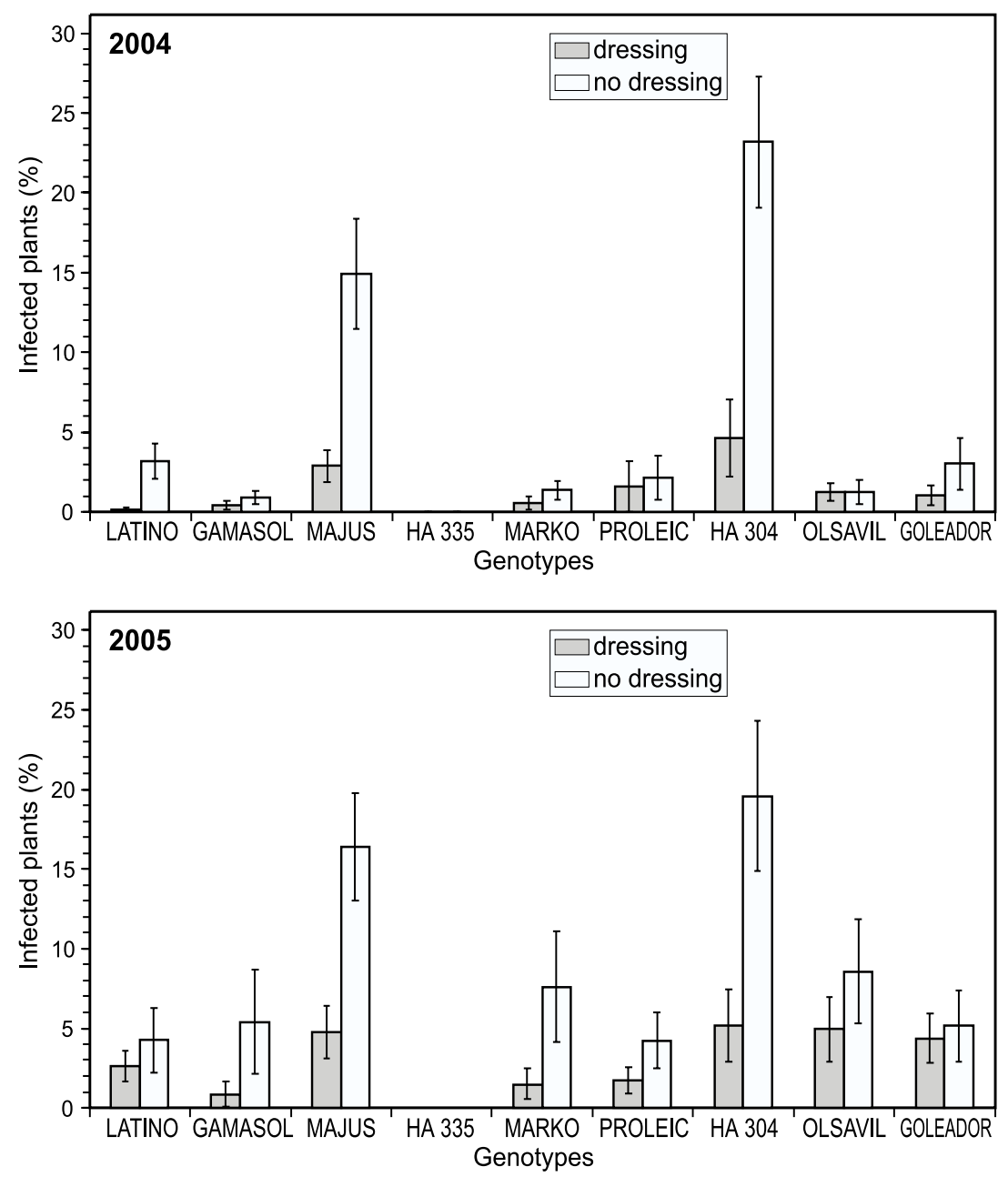

Figure 2: The effect of interaction "genotype $\times$ dressing treatment" on percentage of infected plants, in two experimental years. Vertical bars represent $\pm S E(n=10)$

All the high oleic hybrids, irrespective of seed dressing treatment, showed symptoms caused by $P$. halstedii, suggesting that the $P l$ genes responsible for resistance to race 700 identified in the field were absent in the studied hybrids (Table 3).

Almost all hybrids showed statistically lower average percentages of infection than the susceptible line HA304, with the exception of the hybrid Majus in 2005, which presented statistically higher infection percentages than the others and no difference with respect to HA304 (Figure 2). 
All other high oleic hybrids recorded infection percentages not statistically different from the zero of the resistant check, thus indicating the presence of partial resistance to the pathogen, even if variable and non-race specific.

\section{Seed dressing}

The percentages of infection in the seed dressing treatment, as a mean of the genotypes, were 1.5 and 2.4 in 2004 and 2005, respectively. The interaction sowing time $\mathrm{x}$ dressing treatment revealed a high percentage of infected plants in the first sowing date in $2004(4.7 \%)$ and first and second sowing dates in 2005 (5.2 and $3.6 \%$, respectively). However, the incidence of infected plants was significantly reduced by the seed dressing treatment with respect to the no seed dressing variant, with the exception of the third and fourth sowing dates in 2005, when the infection level was very low (Figure 3).
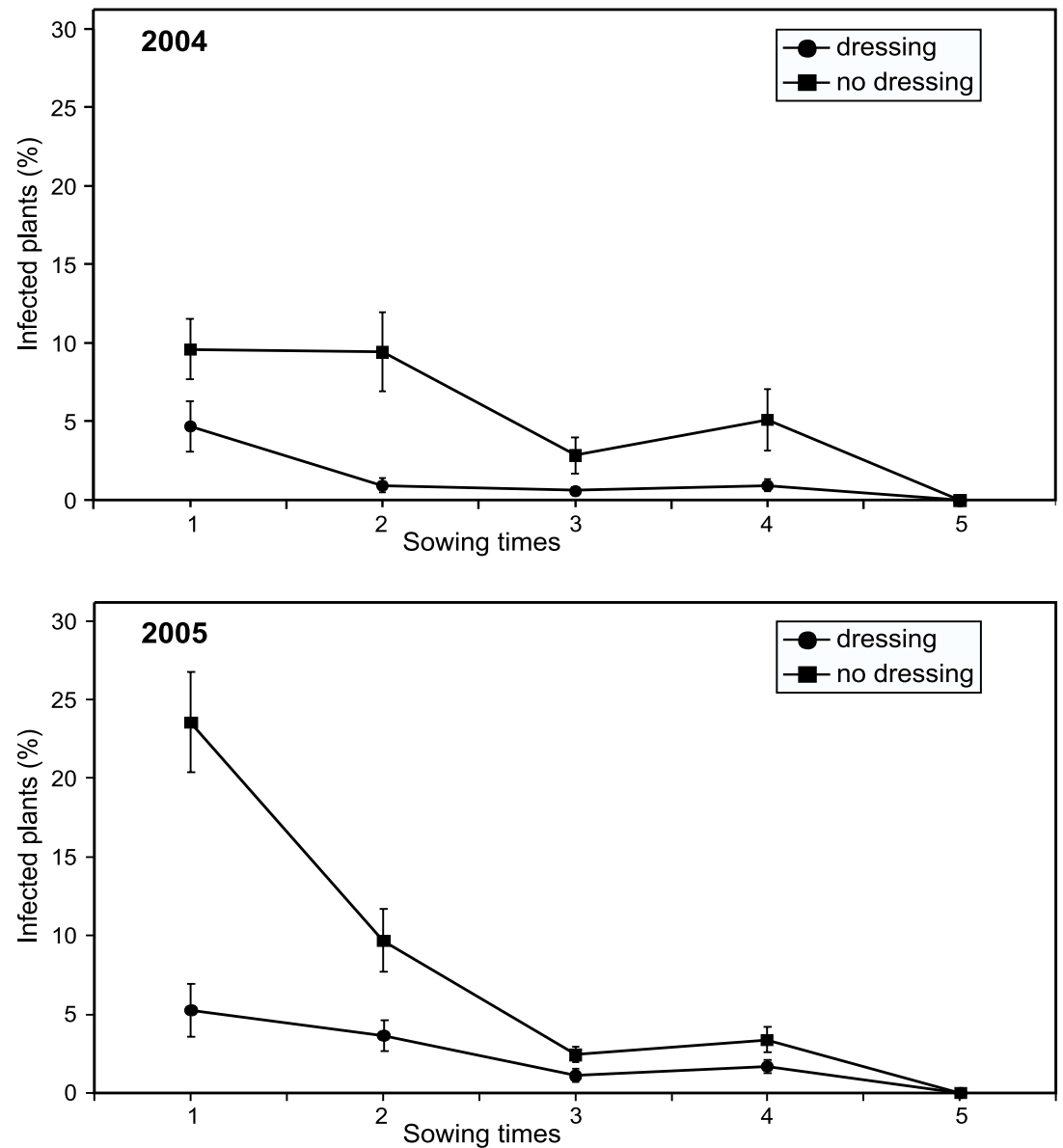

Figure 3: The effect of interaction "sowing time $\times$ dressing treatment" on percentage of infected plants, in two experimental years. Vertical bars represent $\pm S E(n=18)$ 
The efficacy of metalaxyl in the seed dressing variants (as mean of sowing date) was estimated by the response of a susceptible line HA304. It showed 4.6 and $5.2 \%$ of infected plants in 2004 and 2005, respectively (Figure 3), with a maximum of 19.6 and $7.9 \%$ in the first sowing dates.

These percentages are undoubtedly very high if compared with $0.9 \%$ recorded by Gulya (2000), in a study conducted in some areas of North America, in which the author discussed the "high incidence of metalaxyl-resistant mildew isolates". However, to reach the same conclusion in this trial would appear to be premature, because the treatment efficacy might also have been reduced by rainfall events, which could have washed the fungicide's active ingredient off the seeds before it penetrated, a probability also indicated by Delos (1999). In fact, consistent rainfall events were recorded in the days immediately following the first sowing date in both 2004 and 2005 (Figure 1).

\section{Sowing date}

Infection development was studied considering exclusively the no seed dressing HA304 genotype at five different sowing dates, with observations made during five plant growth stages (Figure 4).

The highest levels of infection were recorded in the sowings before mid-April (the first two sowing dates), while no detectable level of infection was found in the last sowing date, in mid-May. The number of infected plants increased significantly until the second phenological stage (2-4 true leaves) and then remained almost constant. This result indicates that plant sensitivity to the primary infection decreases as the plant develops, as reported by other authors (Delos et al., 2000). This was confirmed for the fourth sowing date of 2004, when a significant increase in infection was recorded between the first and second stage (from cotyledon stage to 2-4 true leaves); it was not confirmed for the first and second sowing dates with more developed plants, but identical environmental conditions (Figure 4).

\section{Environmental conditions}

Both rain and soil water content are necessary to trigger the initial infection and disease development, taking into account that a reasonable free soil water content allows the pathogen zoospores to survive and move around (Delanoe, 1972; Zimmer and Hoes, 1978). In particular, Delos et al. (2000) quantified an amount of at least $20 \mathrm{~mm}$ of rain accumulated in the period 5 days before and 5 days after sowing, as the minimum limit for the infection.

However, in the trial conditions, the water availability was not a limiting factor, as no relationship could be found between accumulated rainfall (at 5 and 10 days before sowing, 10 days around sowing and 5 and 10 days after sowing) and percentage of infection. 

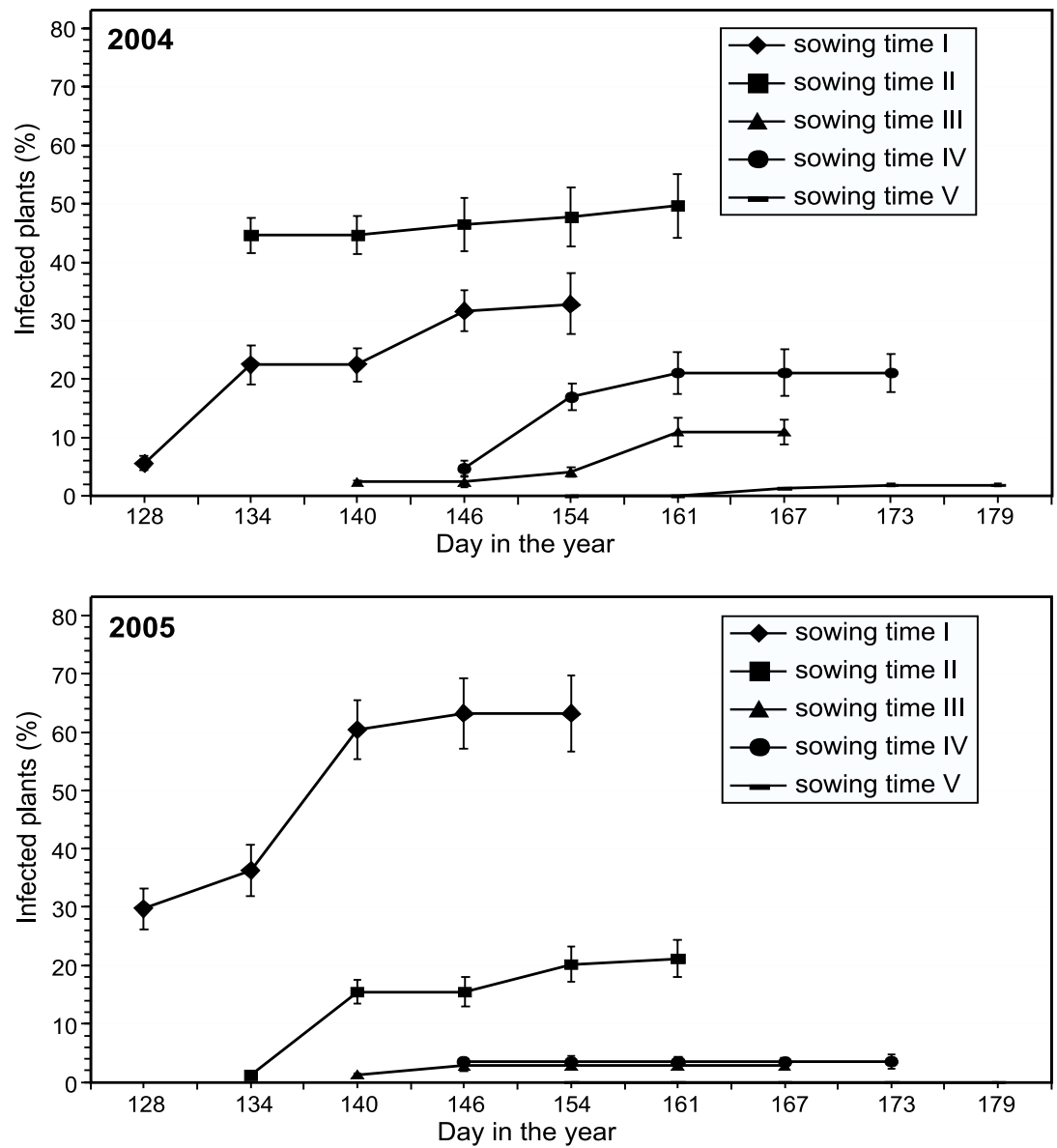

Figure 4: Time-course of downy mildew infection for the different sowing times. Data are referred to the susceptible genotype HA 304 without seed dressing. Vertical bars reprent $\pm \mathrm{SE}(n=20)$

Conversely, air temperature clearly had an effect on the level of infection and percentage of attack. The mainly predictive thermal variable, among those tested, was the average of the mean air temperatures for the 5 days post-sowing $\left(T_{5 p}\right)$. It was observed that the level of infection tended to decrease slowly at temperatures higher than $15^{\circ} \mathrm{C}$. It was also observed that no infection was recorded at mean temperatures above $17^{\circ} \mathrm{C}$ (Figure 6), confirming the negative influence of high temperature on the germination of oospores and on myceliae development in plant tissues (Iliescu et al., 1977). The temperatures in excess of this threshold could be responsible for the absence of symptoms in the last sowing date ( 11 and 17 May, in 2004 and 2005, respectively). 

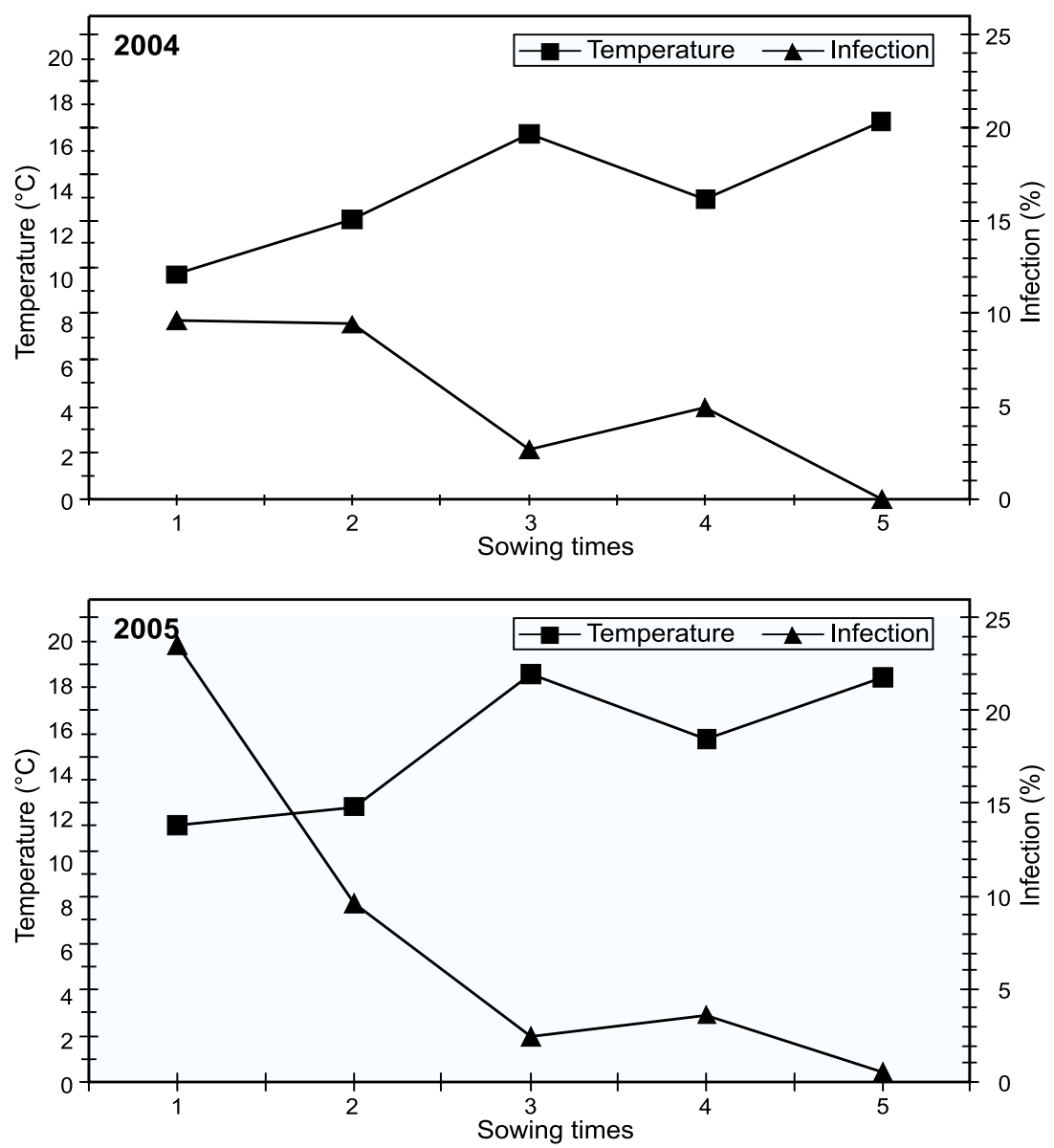

Figure 5: Relationship between infection (as \% of plant infected) and air temperature measured 5 days after planting, in genotypes without seed dressing.

\section{CONCLUSIONS}

Despite the lack of specific genes of resistance to the race detected in the field trial, the high-oleic hybrids studied (except for the cultivar Majus) displayed partial resistance to downy mildew. This could be due to the presence of a partial polygenic, non-qualitative and non-specific resistance and had probably been involuntarily used during genetic breeding programs. Further research, such as the development of new specific tests for verifying this kind of resistance in the growth chamber and the study of the inheritance of this character, could confirm this hypothesis. The possibility of combining both race-specific and non race-specific 
genes in one genotype could allow a more long-lasting resistance to mutations of the pathogen to be obtained, thus limiting the rapid multiplication of new more virulent races (Tourvieille de Labrouche, 2004). Molecular techniques could also be used for polymorphism identification in both inter- and intra-racial populations from different origins (Roeckel-Drevet et al., 2003) to gain a better understanding of the rapid genetic evolution of the parasite in recent years.

The hypothesis of development of some metalaxyl-resistant downy mildew strains, supported by the results obtained in the study, could be explained by the long-term use of metalaxyl as an active ingredient for seed dressing to avoid infections of susceptible germplasm during breeding programs. In order to confirm this hypothesis, further research is required, such as specific tests in controlled conditions, using inocula obtained from single sporangia from the inoculum of the race detected in the environment, according to Molinero Ruiz et al. (2002). However, based on the data obtained it can be argued that the seed treatment with metalaxyl, combined with the partial genetic resistance displayed by almost all the tested hybrids, has limited the severity of $P$. halstedii attack to a maximum of $5 \%$ infected plants.

The influence of temperature on infection development was confirmed, whereas no significant effects were observed regarding rainfall and air humidity, probably because humidity has never been a limiting factor in the trial environment.

As regards the fundamental role of temperature in the onset and spread of downy mildew, the average air temperatures most favorable for infection ranged from 10 to $15^{\circ} \mathrm{C}$. It also appears that an average temperature above $17^{\circ} \mathrm{C}$ during seed germination helps the seed to avoid infection. The next objective will therefore be the elaboration and calibration of the infection prediction model that takes into account the aggressiveness and spread of the pathogen in an area and the correlated local climate and edaphic characteristics.

In some cases a high level of attack has been recorded even when seed dressing is done. Further research is necessary to elucidate the reason for the lower efficacy of the fungicide. Within this context, the importance must be stressed of adopting integrated control measures that include a suitable crop rotation to decrease the amount of inoculum in the soil.

\section{ACKNOWLEDGEMENTS}

The research was conducted with a grant from MIUR (PRIN 2003) project "Use of radar data for the validation of agrometeorological models in Friuli-Venezia Giulia" coordinated by F. Danuso. This work has been made possible thanks to the exchange of Italian and Romanian researchers, as part of the project "NATO SCIENCE PROGRAM, Cooperative Science and Technology Sub-Program, COLLABORATIVE LINKAGE GRANT no. 980196", coordinated by M. Baldini. We would also like to thank Prof. Giuseppe Firrao, of the Department of Biology Applied to Plant Defense, Udine University, for his useful comments on the manuscript. 


\section{REFERENCES}

Albourie, J.M., Tourvieille, J., Tourvieille de Labrouhe, D., 1998. Resistance to metalaxyl in isolate of the sunflower pathogen Plasmopara halsedii. Eur. J. Plant Pathol. 104: 235242 .

Delanoe, D., 1972. Biologie et epidemiology du milldiou du tournesol (Plasmopara helianthi Novot.). Inf. Tech. CETIOM 29: 1-47.

Delanoe, D., Hemant, C., 1972. Role des zoosporange et des zoospores dans le contaminaton du tournesol par le mildiou. In: Proceedings of the $5^{\text {th }}$ International Sunflower Conference, Clermond-Ferrand, 25-29 July, pp.152-155.

Delos, M., 1999. Tournesol: un indicateur de risque pour prevoir le mildiou. Oleoscope- Bulletin du CETIOM 50: 24-25.

Delos, M., Eychenne, N., Birba, I., Fabry, C., 2000. Etude des facteurs explicant les fluctuations des attaques de Plasmopara halstedii en France. In: Proceedings of the $15^{\text {th }}$ International Sunflower Conference, Toulouse, France, 12-15 June 2000. Vol. II pp. I.43-I.48.

Goossen, P.G., Sackston, W.E., 1968. Transmission and biology of sunflower downy mildew. Can. J. Bot. 46: 5-10.

Gulya, T.J., 2000. Metalaxyl resistance in sunflower downy mildew and control through genetics and alternative fungicides. In: Proceedings of the $15^{\text {th }}$ International Sunflower Conference, Toulouse, France, 12-15 June 2000. Vol. II. pp. I.79-I.85.

Iliescu, H., 1979. Control of Plasmopara halstedii by chemical treatments. Helia 2: 65-67.

Iliescu, H., Vranceanu, A.V., Pirvu, N., 1977. Unele aspecte privind etiologia manei florii-soarelui si diseminarea ciupercii Plasmopara helianthi Novot. Analele ICCPT, Vol. XLII: 353-361.

Kolte, S.J., 1985. Diseases of annual edible oilseed crops. Vol. 3, Sunflower, Safflower \& Niger Seed Diseases. CRC Press, Inc., Boca Raton, USA.

Molinero-Ruiz, L., Dominguez, J., Melero Vara, J.M., 2000. Evaluation of Spanish isolates of Plasmopara halstedii for tolerance to metalaxyl. Helia 23: 33-38.

Molinero-Ruiz, L., Dominguez, J., Melero Vara, J.M., 2002. Races of isolates of Plasmopara helianthi from Spain and studies on their virulence. Plant Diseases Vol. 86(7): 736-740.

Roeckel-Drevet, P., Tourvieille, J., Gulya, T.J., Charmet, G., Nicolas, P., Tourvieille de Labrouhe, D., 2003. Molecular variability of sunflower downy mildew, Plasmopara halstedii, from different continents. Can. J. Microbiol. 49: 492-502.

Sackston, W.E., 1981. Downy mildew of sunflower. In: The Downy Mildews (Ed. by Spencer, D.M.), pp. 545-575. Academic Press, London, UK.

Tourvieille de Labrouhe, D., Gulya, T.J., Maširević, S., Penaud, A., Rashid, Y.K. e Viranyi, F., 2000. New nomenclature of races of Plasmopara halstedii (sunflower Downy Mildew). In: Proceedings of the $15^{\text {th }}$ International Sunflower Conference, Toulouse, France, 12-15 June 2000. Vol. III: I.61-I.65.

Tourvieille de Labrouhe, D., Serre, F., Walser, P., Philippon, J., Vear, F., Tardin, M.C., Andre T., Castellanet, P., Chatre, S., Costes, M., Jouve, P., Madeuf, J.L., Mezzarobba A., Plegades, J., Pauchet, I., Mestries, E., Penaud, A., Pinochet, X., Seriyes, H., Griveau, Y., 2004. Partial, non-specific resistance to downy mildew in cultivated sunflower lines. In: Proceeding of the $16^{\text {th }}$ International Sunflower Conference, Fargo, North Dakota, USA, August 29 - September 2, 2004. Vol. I: 105-110.

Vear, F., Leclercq, P., 1971. Deux nouveaux genes de resistance au mildiou du tournesol. Ann. Amelior. Plantes 21: 215-255.

Vear, F., Phillipon, J., Roche, S., Walser, P., Tourvieille de Labrouhe, D., Mouzeyar, S., Nicolas, P., 2000. Genetical analysis of the sunflower downy mildew resistance gene Pl5. In: Proceedings of the $15^{\text {th }}$ International Sunflower Conference, Toulouse, France, 12-15 June 2000. Vol. II: pp. J31-J36.

Vranceanu, A.V., Pirvu, N., Stonescu, F.M. 1981. New sunflower downy mildew resistance genes and their management. Helia 4: 23-27.

Zimmer, D.E., Hoes, J.A., 1978. Diseases. In: Sunflower science and technology (Ed. by Carter, J.F.), pp. 225-262. American Society of Agronomy, Madison, USA.

Zimmer, D.E., Kinman, M.L., 1972. Downy mildew resistance in cultivated sunflower and its inheritance. Crop Sci. 12: 749-751. 


\title{
INFECCIÓN DE HÍBRIDOS ALTO OLEICOS DE GIRASOL CON EL TIZÓN (Plasmopara halstedii) EN ITALIA DEL NORTE
}

\author{
RESUMEN
}

El trabajo fue emprendido con el objetivo de calificación del comportamiento de algunos híbridos alto oleicos de girasol hacia la raza Plasmopara halstedii, presente en las alrededores, y de analizar los principales factores climáticos que influyen en el desarrollo y divulgación de la enfermedad, todo con el objetivo de establecer la base para el desarrollo del modelo de pronóstico de presentación de la enfermedad. La raza está determinada mediante infección artificial de las líneas consanguíneas (inbred) diferenciales, en la cámara. El experimento de campo fue emprendido para estudiar la influencia de los siguientes factores: genotipos, tiempos de siembra y tratamiento de semilla, en la evaluación de la infección con el hongo $P$. halstedii durante diferentes fases de desarrollo. Los genes $P l$ que condicionan la resistencia a la raza 700 , cuya presencia está determinada en la región investigada, y que son denominados de acuerdo con el código internacional, no fueron encontrados en los híbridos alto oleicos estudiados que, mientras tanto, mostraron una resistencia al Tizón parcial, probablemente por causa de una resistencia parcialmente poligénica, no cualitativa y no específica, a la raza determinada. El tratamiento de la semilla con Metalaxil, ayudó en que la intensidad de ataques de $P$. halstedii se redujera en $5 \%$ de plantas infectadas, con un máximo de $19.6 \%$ en la variante de control sensible. En cuanto a las condiciones del medio, la accesibilidad de la humedad no fue factor limitante para la infección, mientras que la temperatura del aire más favorable media, durante los 5 días tras la siembra, variaba entre 10 y $15^{\circ} \mathrm{C}$.

\section{INFECTION DE MILDIOU (Plasmopara halstedii) DANS LES HYBRIDES DE TOURNESOL À HAUTE TENEUR OLÉIQUE EN ITALIE DU NORD}

\section{RÉSUMÉ}

Cette étude a été faite dans le but d'évaluer le comportement d'hybrides de tournesol à haute teneur oléique en présence de la race Plasmopara halstedii qui se trouve dans l'environnement et pour analyser les principaux facteurs climatiques affectant le développement et la propagation de cette maladie, ceci pour établir la base de développement d'un modèle de prédiction d'apparition de la maladie. La race a été déterminée au moyen de l'infection artificielle de souches pures différentielles en laboratoire. Une expérience sur le terrain a été entreprise pour examiner l'effet des facteurs suivants sur le pourcentage de l'infection par le champignon $P$. halstedii au cours de différentes phases de développement: génotypes, temps des semailles et du traitement des akènes. Les gènes $P l$ qui conditionnent la résistance à la race 700 , dont la présence a été confirmée dans la région d'essai et qui sont nommés selon le code international, n'ont pas été trouvés dans les hybrides à haute teneur oléique observés qui ont, cependant, montré une résistance partielle au mildiou, probablement grâce à une résistance polygénique, non qualitative et non spécifique à la race détectée. Le traitement des akènes par du métalaxyl a contribué à limiter la gravité de l'attaque de $P$. halstedii à $5 \%$ des plantes infectées, mais avec un 
maximum de 19,6\% dans la variété de contrôle sensible. Pour ce qui concerne les conditions de l'environnement, la disponibilité de l'eau n'a pas été un facteur limitatif de l'infection tandis que la température moyenne de l'air la plus favorable au cours des 5 jours suivant les semailles était de 10 à $15^{\circ} \mathrm{C}$.

Presented at: 